\title{
Zakres podmiotowy dofinansowania do wynagrodzeń pracowników wypłacanego ze środków Funduszu Gwarantowanych Świadczeń Pracowniczych w związku ze zwalczaniem skutków epidemii COVID-19
}

\begin{abstract}
The Subjective Scope of Subsidies to Employee Salaries Paid from the Guaranteed Employee Benefits Fund in Connection with Combating the Effects of the COVID-19 Pandemic

Summary

This article presents an analysis of the group of entities to whom the Polish legislature has granted assistance in the form of the co-financing of employees' wages from the Guaranteed Employee Claims Fund due to the worsening of the entities' economic situation as a result of the COVID-19 epidemic. This policy has raised serious doubts in terms of interpretation and axiology. Moreover, the list of eligible entities has undergone numerous and dynamic changes, the purpose and justification of which have also been regarded as controversial. The author has carried out a critical analysis of these solutions. Keywords: epidemic, co-financing for remuneration, entrepreneur, non-governmental organizations, employee, Guaranteed Employee Claims Fund
\end{abstract}

\section{Uwagi wprowadzające}

Jednym z głównych instrumentów wsparcia dla podmiotów działających w obrocie gospodarczym (i nie tylko gospodarczym) w związku z epidemią COVID-19 jest dofinansowanie do wynagrodzeń pracowników objętych obniżonym wymiarem czasu pracy lub przestojem ekonomicznym, wypłacane przez Fundusz Gwarantowanych Świadczeń Pracowniczych, przewidziane $\mathrm{w}$ art. $15 \mathrm{~g}$ ustawy o zapobieganiu i zwalczaniu COVID-19 ${ }^{1}$. Jest to instrument o dość złożonym charakterze,

${ }^{1}$ Ustawa z dnia 31 marca 2020 r. o zmianie ustawy o szczególnych rozwiązaniach związanych z zapobieganiem, przeciwdziałaniem i zwalczaniem COVID-19, innych 
który z prawem pracy wiąże forma pomocy w postaci dofinansowania do wynagrodzenia pracowników, uzależnienie udzielenia pomocy od zawarcia porozumienia zbiorowego obejmującego pracowników przestojem ekonomicznym lub obniżonym wymiarem czasu pracy, oraz zakaz wypowiadania umów o pracę pracownikom, do wynagrodzeń których wypłacone zostało dofinansowanie.

Jednym z ciekawszych zagadnień, jakie się pojawiło na tle stosowania art. 15g ustawy o zapobieganiu i zwalczaniu COVID-19 jest ewolucja katalogu podmiotów uprawnionych do występowania z wnioskami o dofinansowanie do wynagrodzeń. Wszystkie kolejne odsłony tzw. Tarczy antykryzysowej² zawierały modyfikacje zakresu podmiotów uprawnionych do tych świadczeń. Regulacja stawała się przez to coraz bardziej kazuistyczna i coraz mniej czytelna, a jej pierwotnie dość klarowne aksjologiczne uzasadnienie ulegało coraz większemu zatarciu. Jednocześnie jest to problematyka o bardzo doniosłym znaczeniu społecznym - w kryzysie wywołanym epidemią kwestia otrzymania bądź nieotrzymania tych świadczeń mogła przesądzić o dalszym losie podmiotu i zatrudnianych przez niego pracowników. Niniejszy tekst będzie stanowił próbę pogłębionej analizy tej ważkiej, w mojej ocenie, kwestii ustawodawstwa antykryzysowego.

Zakres podmiotów uprawnionych do wystąpienia z wnioskiem o dofinansowanie wynagrodzeń pracowników objętych obniżonym wymiarem czasu pracy lub przestojem ekonomicznym został uregulowany obowiązującym od dnia 1 kwietnia 2020 r. art. $15 \mathrm{~g}$ ust. 1 ustawy o zapobieganiu i zwalczaniu COVID-19, oraz wprowadzonym tzw. Tarczą 4.0 art. 15gg, który nie zawiera w tym względzie samoistnej regulacji, ale odsyła do art. $15 \mathrm{~g}$ ust. 1 . Można zatem stwierdzić, że to art. $15 \mathrm{~g}$ ust. 1 ustala zakres podmiotów uprawnionych do występowania o dofinansowanie do wynagrodzeń pracowników z Funduszu

chorób zakaźnych oraz wywołanych nimi sytuacji kryzysowych oraz niektórych innych ustaw (Dz.U. 2020, poz. 568) zwana Tarczą 1.0.

${ }^{2}$ Ustawa z dnia 16 kwietnia 2020 r. o szczególnych instrumentach wsparcia w związku z rozprzestrzenianiem się wirusa SARS-CoV-2 (Dz.U. 2020, poz. 695), zwana Tarczą 2.0, ustawa z dnia 14 maja 2020 r. o zmianie niektórych ustaw w zakresie działań osłonowych w związku z rozprzestrzenianiem się wirusa SARS-CoV-2 (Dz.U. 2020, poz. 875), zwana Tarczą 3.0. oraz ustawa z dnia 19 czerwca 2020 r. o dopłatach do oprocentowania kredytów bankowych udzielnych przedsiębiorcom dotkniętym skutkami COVID-19 oraz przyspieszonym postępowaniu o zatwierdzenie układu w związku z wystąpieniem COVID-19, zwana Tarczą 4.0. 
Zakres podmiotowy dofinansowania do wynagrodzeń pracowników...

Gwarantowanych Świadczeń Pracowniczych, jemu też będzie poświęcony niniejszy tekst.

Od strony osób uprawnionych do uzyskania dofinansowania zakres podmiotowy ustawy wynika $\mathrm{z}$ art. $15 \mathrm{~g}$ ust. 4 . W tym jednak przypadku należy mieć świadomość, że ograniczenie zakresu podmiotowego ma w istocie podwójny charakter - żeby pracownik, o którym mowa $\mathrm{w}$ art. $15 \mathrm{~g}$ ust. 4 otrzymał dofinansowanie do wynagrodzenia, w pierwszej kolejności musi być zatrudniony przez podmiot uprawniony do wnioskowania o dofinansowanie, wskazany w art. $15 \mathrm{~g}$ ust. 1 ustawy o COVID-19.

\section{Przyjęta metoda regulacji}

W pierwszej kolejności należy się odnieść do metody, jaką obrał ustawodawca regulując zakres podmiotowy art. $15 \mathrm{~g}$ ust. 1 ustawy o COVID-19, czyli zakres podmiotów uprawnionych do występowania o dofinansowanie do wynagrodzeń pracowników. Ustawodawca posłużył się w tym przypadku metodą taksatywnego wyliczenia kategorii podmiotów uprawnionych do występowania o przyznanie świadczeń. Przy czym, co również znamienne, katalog podmiotów uprawnionych do występowania o wypłatę świadczeń na dofinansowanie wynagrodzeń pracowników nie został w nim wskazany bezpośrednio, ale przez odesłania do innych przepisów. Zastosowana technika legislacyjna jest dość skomplikowana - w rezultacie rzeczywisty zakres podmiotowy art. 15g ust. 1 wyznaczają przepisy ustaw, do których zawiera on odesłanie: art. 4 ust. 1 lub 2 ustawy prawo przedsiębiorców ${ }^{3}$, art. 2 ust. 3 oraz art. 3 ust. 3 ustawy o organizacjach pożytku publicznego i o wolontariacie ${ }^{4}$, przepisy o stosunku państwa do kościoła katolickiego w RP i innych związków wyznaniowych ${ }^{5}$ oraz przepisy ustawy o prowadzeniu działalności kulturalnej ${ }^{6}$.

3 Ustawa z dnia 6 marca 2018 r. Prawo przedsiębiorców (tj. Dz.U. 2018, poz. 1992).

${ }^{4}$ Ustawa z dnia 24 kwietnia 2003 r. o działalności pożytku publicznego i o wolontariacie (tj. Dz.U. 2020, poz. 1057).

${ }^{5}$ Ustawa z dnia 17 maja 1989 r. o stosunku Państwa do Kościoła Katolickiego w Rzeczpospolitej Polskiej (tj. Dz.U. 2019, poz. 1347) oraz ustawa z dnia 17 maja 1989 r. o gwarancjach wolności sumienia i wyznania (tj. Dz.U. 2017, poz. 1153).

${ }^{6}$ Ustawa z dnia 25 października 1991 r. o organizowaniu i prowadzeniu działalności kulturalnej (tj. Dz.U. 2020, poz. 194). 
Podmioty te muszą jednocześnie spełniać dodatkowe przesłanki, jedną o charakterze pozytywnym, dwie o charakterze negatywnym. Pierwsza dotyczy spadku obrotów finansowych w stopniu określonym w $15 \mathrm{~g}$ ust. 9 ustawy o zapobieganiu i zwalczaniu COVID-19, czyli nie mniej niż o 15\%, obliczone jako stosunek łącznych obrotów w ciągu dowolnie wskazanych 2 kolejnych miesięcy kalendarzowych przypadających w okresie po dniu 1 stycznia 2020 r. do dnia poprzedzającego dzień złożenia wniosku, o którym mowa w ust. 1, w porównaniu do łącznych obrotów z analogicznych 2 kolejnych miesięcy kalendarzowych roku poprzedniego, lub nie mniej niż $25 \%$, obliczone jako stosunek obrotów $\mathrm{z}$ dowolnie wskazanego miesiąca kalendarzowego przypadającego po dniu 1 stycznia 2020 r. do dnia poprzedzającego dzień złożenia wniosku, o którym mowa w ust. 1, w porównaniu do obrotów z miesiąca poprzedniego. Przesłanka ta ma wiązać otrzymaną ze środków publicznych pomoc z pogorszeniem na skutek epidemii koronawirusa i jej ekonomicznych skutków kondycji finansowej podmiotu uprawnionego.

Przesłanki negatywne zostały wyznaczone przez odesłanie do art. 3 ust. 1 pkt. 2 i 3 ustawy z dnia 11 października 2013 r. o szczególnych rozwiązaniach związanych $\mathrm{z}$ ochroną miejsc pracy ${ }^{7}$. Pierwsza dotyczy niespełniania przez podmiot wskazany $\mathrm{w}$ art. $15 \mathrm{~g}$ ust. 1 przesłanek do ogłoszenia upadłości, wynikających z ustawy prawo upadłościowe. $\mathrm{W}$ tym zakresie przepisy prawa upadłościowego (art. $11 \mathrm{i}$ art. 13 ust. 3 prawa upadłościowego) należy stosować bez żadnych modyfikacji. W praktyce stosowania przepisu pojawił się jednak problem, czy uprawnione do wnioskowania o dofinansowanie sa podmioty $\mathrm{w}$ stosunku do których otwarto postępowanie restrukturyzacyjne. Przesłanką otwarcia postępowania restrukturyzacyjnego jest bowiem niewypłacalność w rozumieniu art. 11 ustawy prawo upadłościowe lub stan zagrożenia niewypłacalnością. Oznaczałoby to, że te podmioty w restrukturyzacji, które spełniają przesłanki niewypłacalności w rozumieniu przepisów prawa upadłościowego, nie mogą wystąpić o dofinansowanie. Te jednak, które dopiero są zagrożone niewypłacalnością nie są wyłączone z zakresu art. 15g ust. 1 ustawy o COVID-19. Merytoryczne ustalenie, czy przedsiębiorca $\mathrm{w}$ restrukturyzacji jest uprawniony do wnioskowania o dofinansowanie do wynagrodzeń pracowników jest

7 Ustawa z dnia 13 października 2013 r. o szczególnych rozwiązaniach związanych z ochroną miejsc pracy (tj. Dz.U. 2019, poz. 669). 
trudne i wymaga specjalistycznej wiedzy ${ }^{8}$. W praktyce rozstrzygały o tym oświadczenia składane przez osoby reprezentujące podmiot, wobec którego wszczęto postępowanie restrukturyzacyjne.

Druga przesłanka negatywna to niezaleganie $\mathrm{w}$ regulowaniu zobowiązań podatkowych oraz składek na ubezpieczenie społeczne, ubezpieczenie zdrowotne, Fundusz Pracy, Fundusz Gwarantowanych Świadczeń Pracowniczych oraz Fundusz Solidarnościowy do końca III kwartału 2019 r. ${ }^{9}$ W tym przypadku ustawodawca posłużył się dość specyficzną metodą regulacji - art. 15g ust. 1 odsyła do art. 3 ust. 2 ustawy o szczególnych rozwiązaniach związanych $\mathrm{z}$ ochroną miejsc pracy, jednakże w swojej treści wprowadza ograniczenie czasowe tej przesłanki do końca III kwartału 2019 r. Należy założyć, że celem tego ograniczenia jest niepozbawienie prawa do występowania z wnioskiem o dofinansowanie podmiotów, których zaległości w zakresie wymienionych danin publicznych powstały $\mathrm{w}$ konsekwencji utrudnień w prowadzeniu działalności wywołanych przez epidemię COVID-19.

Co jednak $\mathrm{w}$ analizowanym przepisie zwraca największą uwagę, to brak odwołania do pracodawczego statusu podmiotów wymienionych $\mathrm{w}$ art. $15 \mathrm{~g}$ ust. 1 . Ustawodawca $\mathrm{w}$ żadnym miejscu bezpośrednio nie wskazuje na więź prawną łączącą te podmioty z pracownikami, do których wynagrodzeń mają uzyskać dofinansowanie. Nie ma tu na przykład występującego $\mathrm{w}$ art. 2 ust. 1 ustawy o ochronie roszczeń pracowniczych $\mathrm{w}$ razie niewypłacalności pracodawcy sformułowania „pracodawca będący przedsiębiorcą $\mathrm{w}$ rozumieniu art. 4 ust. 1 lub 2 ustawy prawo przedsiębiorców", który sprawił, że zakresem podmiotowym tego przepisu objęty był tylko taki podmiot, który spełniał łącznie obydwa te kryteria. Podobna do art. $15 \mathrm{~g}$ ust. 1 (zwłaszcza $\mathrm{w}$ pierwotnym jego brzmieniu) regulacja występowała $\mathrm{w}$ art. 3 ustawy o szczególnych rozwiązaniach związanych z ochroną miejsc pracy, zgodnie z którym przepisy ustawy stosuje się do przedsiębiorcy w rozumieniu art. 4 ust. 1 lub 2 ustawy z dnia 6 marca 2018 r. - Prawo

8 Por. K. Ksıє̨żYK, w: Tarcza antykryzysowa 1.0 - 3.0. Szczególne rozwiazzania w prawie pracy, prawie urzędniczym i prawie ubezpieczeń społecznych. Komentarz. Red. K.W. Baran. Warszawa 2020, s. 153.

${ }_{9}$ Ustawodawca posłużył się w tym przypadku konstrukcją odesłania do art. 3 ustawy o szczególnych rozwiązaniach związanych z ochroną miejsc pracy. 
przedsiębiorcó $\mathrm{w}^{10}$. W tym jednak przypadku z art. 1 pkt. 2 i 2a ustawy o szczególnych rozwiązaniach związanych z ochroną miejsc pracy wynikało, że chodzi o pracowników zatrudnionych u przedsiębiorcy, o którym mowa $\mathrm{w}$ art. $3 . \mathrm{W}$ art. $15 \mathrm{~g}$ ust. 1 również jednak brak takiego powiązania ze statusem pracodawcy zatrudniającego pracowników. Powstaje zatem pytanie, czy między podmiotem występującym o dofinansowanie a pracownikiem, do którego wynagrodzenia dofinansowanie to przysługuje $\mathrm{w}$ każdym przypadku musi istnieć stosunek pracy.

Kwestia powyższa nabrała szczególnie istotnego znaczenia w odniesieniu do podmiotów wskazanych $\mathrm{w}$ art. $15 \mathrm{~g}$ ust. 1, w których strukturze organizacyjnej wyodrębnione zostały jednostki organizacyjne mające prawo do zatrudniania pracowników we własnym imieniu (pracodawcy wewnętrzni). W takim bowiem przypadku powstało pytanie, czy podmiot wskazany $\mathrm{w}$ art. $15 \mathrm{~g}$ ust. 1 mógł występować o dofinansowanie tylko w stosunku do swoich pracowników, czy również w stosunku do pracowników zatrudnianych przez wchodzących w ich skład pracodawców wewnętrznych. Spory interpretacyjne wywoływała również kwestia, czy sam pracodawca wewnętrzny jest podmiotem uprawnionym do występowania $\mathrm{z}$ wnioskiem o dofinansowanie do wynagrodzeń zatrudnianych przez siebie pracowników ${ }^{11}$. W literaturze przedmiotu zaprezentowane zostało stanowisko, w myśl którego „rozwiązaniem mogłoby być wystąpienie z wnioskiem przez przedsiębiorcę, u którego pracodawca wewnętrzny został utworzony. W samym art. $15 \mathrm{~g}$ rozróżnia się przedsiębiorcę i pracodawcę, co zdaje się dodatkowo uzasadniać równoległe umocowanie do działań zarówno dla przedsiębiorcy, jak i utworzonego u niego pracodawcy wewnętrznego"12. Taka też wykładnia - inspirowana w dużej mierze stanowiskiem Ministerstwa Rodziny, Pracy i Polityki Społecznej - stosowana była w praktyce organów przyznających dofinansowanie. Przyjęto zatem, że podmioty wskazane $\mathrm{w}$ art. $15 \mathrm{~g}$ mogą występować o dofinansowanie nie tylko do wynagrodzeń pracowników bezpośrednio zatrudnianych, ale i pracowników zatrudnionych przez ich wewnętrzne

${ }^{10}$ K. KsIĘŻYK, w: Tarcza..., s. 134.

${ }^{11}$ K. KsIĘŻYK, w: Tarcza..., s. 145.

12 Ł. PisarczyK, A. Boguska: Sfera zatrudnienia w działaniach antykryzysowych. Wybrane zagadnienia. „Monitor Prawa Pracy” 2020, nr 5, s. 3. 
jednostki organizacyjne, będące pracodawcami wewnętrznymi w rozumieniu art. 3 k.p. Warunkiem jest zawarcie przez pracodawcę wewnętrznego $\mathrm{z}$ zatrudnianymi pracownikami porozumienia $\mathrm{w}$ sprawie przestoju ekonomicznego lub obniżonego wymiaru czasu pracy. Warto zauważyć, że taka wykładnia nie byłaby możliwa, gdy ustawodawca bezpośrednio wskazał, że podmiot wskazany w art. 15g ust. 1 musi być pracodawcą $\mathrm{w}$ rozumieniu art. 3 k.p. lub że może występować o dofinansowanie dla zatrudnianych przez siebie pracowników ${ }^{13}$. Niezależnie od tego, czy taki kształt regulacji był świadomą decyzją ustawodawcy, czy był to efekt przeoczenia, sformułowanie przepisu pozwoliło na swego rodzaju przełamanie koncepcji zarządczej pracodawcy i objęcie dofinansowaniem większej liczby pracowników.

\section{Ewolucja art. $15 \mathrm{~g}$ ust. 1 ustawy o COVID-19}

Jak już wspomniano wyżej, ustawodawca określił zakres podmiotów uprawnionych do uzyskania dofinansowania do wynagrodzeń z Funduszu Gwarantowanych Świadczeń Pracowniczych za pomoca enumeratywnego wyliczenia ich poszczególnych kategorii. Należy przy tym zauważyć, że katalog ten ulegał dynamicznym zmianom. Krótkie zaprezentowanie tej ewolucji jest konieczne dla dalszych rozważań.

W pierwotnej wersji art. 15g ustawy o COVID-19 jedyną kategorią pomiotów uprawnioną do występowania o wypłatę świadczeń na dofinansowanie do wynagrodzeń pracowników byli przedsiębiorcy w rozumieniu art. 4 ust. 1 i 2 ustawy prawo przedsiębiorców. W świetle tego przepisu status przedsiębiorcy przysługuje podmiotom, które spełniają łącznie dwa kryteria: są osobami prawnymi, jednostkami organizacyjnymi nieposiadającymi osobowości prawnej, ale mającymi zdolność prawną nadaną mocą ustawy, bądź osobami fizycznymi (kryterium podmiotowe), które prowadzą we własnym imieniu i w sposób ciągły działalność gospodarczą (kryterium przedmiotowe) ${ }^{14}$. Dla możliwości uzyskania świadczeń nie ma natomiast znaczenia, czy działalność gospodarcza jest głównym czy ubocznym celem działania danej

13 Takie zastrzeżenie zawiera na przykład art. 15ga ustawy o COVID-19.

${ }^{14}$ Por. R. Bielecki i in.: Komentarz do ustawy - Prawo przedsiębiorców, w: Konstytucja biznesu. Komentarz. Red. M. Wierzbowsкi. WKP 2019, sip.lex.pl. 
jednostki ${ }^{15}$. Do kategorii przedsiębiorców w rozumieniu art. 4 ust. 1 lub 2 ustawy prawo przedsiębiorców należy zatem zaliczyć zarówno podmioty, których głównym lub wręcz jedynym celem funkcjonowania jest prowadzenie działalności gospodarczej (takie jak spółki osobowe, zakłady ubezpieczeniowe, większość spółek kapitałowych) jak i podmioty, których główny cel działalności ma charakter niezarobkowy, a działalność gospodarcza ma charakter subsydiarny i służący wspieraniu ich celów statutowych (jak np. fundacje, związki zawodowe, jednostki samorządu zawodowego) ${ }^{16}$.

Jednak już w kolejnej odsłonie „tarczy antykryzysowej”17 katalog podmiotów uprawnionych do występowania o dofinansowanie do wynagrodzeń pracowników uległ znaczącemu poszerzeniu. Prawo to uzyskały organizacje pozarządowe $w$ rozumieniu art. 3 ust. 2 ustawy o działalności pożytku publicznego i o wolontariacie, niezależnie od tego, czy prowadzą działalność pożytku publicznego.

Zgodnie $\mathrm{z}$ art. 3 ust. 2 ustawy o działalności pożytku publicznego organizacjami pozarządowymi sa, nie będące jednostkami sektora finansów publicznych, w rozumieniu przepisów o finansach publicznych, i nie działające w celu osiągniecia zysku, osoby prawne lub jednostki nieposiadające osobowości prawnej utworzone na podstawie przepisów ustaw, w tym fundacje i stowarzyszenia, z zastrzeżeniem ust. 4. Zgodnie $\mathrm{z}$ art. 3 ust. 4 przepisów działu II nie stosuje się do: 1) partii politycznych; 2) związków zawodowych i organizacji pracodawców; 3) samorządów zawodowych; 4) fundacji, których jedynym fundatorem jest Skarb Państwa lub jednostka samorządu terytorialnego, chyba że: a) przepisy odrębne stanowią inaczej, b) majątek tej fundacji nie jest $\mathrm{w}$ całości mieniem państwowym, mieniem komunalnym lub mieniem pochodzącym $\mathrm{z}$ finansowania środkami publicznymi $\mathrm{w}$ rozumieniu ustawy o finansach publicznych lub c) fundacja prowadzi działalność statutową w zakresie nauki, w szczególności na rzecz nauki; 5) fundacji utworzonych przez partie polityczne; 6) spółek działających na podstawie przepisów o kulturze fizycznej. Nie oznacza to jednak, że wymienione w ust. 4 podmioty nie mogą mieć statusu organizacji pozarządowej. Nie stosuje się wobec nich jedynie przepisów

15 Tamże.

16 Tamże.

17 Tarcza 2.0. 
działu II ustawy dotyczącego organizacji porządku publicznego. Tak więc należy uznać, że partie polityczne i tworzone przez nie fundacje, związki zawodowe i organizacje pracodawców, także samorządy zawodowe mogą stanowić organizację pozarządową (jeżeli spełniają warunki określone w art. 3 ust. 2 ustawy), jedynie nie mogą one uzyskać statusu organizacji pożytku publicznego oraz nie mogą otrzymywać dotacji $\mathrm{w}$ trybie określonym $\mathrm{w}$ ustawie (zgodnie $\mathrm{z}$ art. 3 ust. 4 nie stosuje się do nich działu II ustawy, w którym jest mowa o zasadach uzyskiwania tego statusu oraz o zlecaniu organizacjom realizacji zadań publicznych). Podmioty te mieszczą się zatem w zakresie podmiotowym art. $15 \mathrm{~g}$ ust. 1 ustawy o COVID-19.

Jednocześnie należy wspomnieć, że część podmiotów będących organizacjami pozarządowymi może prowadzić działalność gospodarczą (z reguły działalność ta ma charakter subsydiarny, a dochody z niej wspierają działalność statutową danej organizacji pozarządowej) i z tego tytułu uzyskać również status przedsiębiorcy w rozumieniu art. 4 ust. 1 ustawy prawo przedsiębiorców w zakresie prowadzonej działalności. W takich przypadkach można mówić o podwójnej legitymacji do występowania o dofinansowanie wynagrodzeń pracowników.

Kolejną grupą podmiotów, która przy tej nowelizacji została uprawniona do świadczeń są podmioty, o których mowa w art. 3 ust. 3 ustawy o pożytku publicznym i o wolontariacie. Są to: 1) osoby prawne i jednostki organizacyjne działające na podstawie przepisów o stosunku Państwa do Kościoła Katolickiego w Rzeczypospolitej Polskiej, o stosunku Państwa do innych Kociołów i związków wyznaniowych oraz o gwarancjach wolności sumienia i wyznania, jeżeli ich cele statutowe obejmują prowadzenie działalności pożytku publicznego; 2) stowarzyszenia jednostek samorządu terytorialnego; spółdzielnie socjalne; spółki akcyjne i spółki z ograniczoną odpowiedzialnością oraz kluby sportowe będące spółkami, które nie działają w celu osiągnięcia zysku oraz przeznaczają całość dochodu na realizację celów statutowych oraz nie przeznaczają zysku do podziału między udziałowców, akcjonariuszy i pracowników. W odniesieniu do kościelnych osób prawnych i ich jednostek organizacyjnych dalszych zmian dokonała Tarcza 4.0., w wyniku których w art. $15 \mathrm{~g}$ kościelne osoby prawne i ich jednostki organizacyjne zostały expressis verbis wymienione jako podmioty uprawnione do uzyskiwania dofinansowania. Jednocześnie 
ustawodawca utrzymał $\mathrm{w}$ mocy tę część art. 15g ust. 1, która jako podmioty uprawnione do wnioskowania o dofinansowanie wskazuje podmioty wymienione $\mathrm{w}$ art. 3 ust. 3 ustawy o działalności pożytku publicznego i o wolontariacie, który również - jak wskazano wyżej obejmuje kościelne osoby prawne i ich jednostki organizacyjne. Różnica polega na tym, że kościelne osoby prawne i ich jednostki organizacyjne ubiegające się o dofinansowanie jako podmioty wskazane $\mathrm{w}$ art. 3 ust. 3 ustawy o działalności pożytku publicznego i o wolontariacie musiały dodatkowo spełniać warunek posiadania w swych celach statutowych prowadzenia działalności pożytku publicznego. Obecnie, po zmianie przepisu wprowadzonego Tarczą 4.0, już tego dodatkowego kryterium spełniać nie muszą. $W$ istocie doszło zatem do dalszego poszerzenia możliwości ubiegania się kościelnych osób prawnych i ich jednostek organizacyjnych o dofinansowanie. Należy również zauważyć, że na tej podstawie prawem do wnioskowania o dofinansowanie z Funduszu Gwarantowanych Świadczeń Pracowniczych został objęty dość różnorodny i trudny do sprecyzowania krąg podmiotów. O ile bowiem zakres kościelnych osób prawnych da się dość precyzyjnie ustalić na podstawie art. 6-10 ustawy o stosunku państwa do Kościoła Katolickiego w RP, o tyle tworzenie ich jednostek organizacyjnych zostało poddane dość skromnej regulacji w art. 12 ustawy o stosunku państwa do Kościoła Katolickiego w RP. Przepis ten mówi jedynie, że kościelne wydawnictwa, zakłady wytwórcze, usługowe i handlowe, zakłady charytatywno-opiekuńcze, szkoły i inne placówki oświatowo-wychowawcze nieposiadające osobowości prawnej, działają w ramach kościelnych osób prawnych, które je powołały. Należy również odnotować, że tworzenie jednostek organizacyjnych kościelnych osób prawnych uważa się za wewnętrzną sprawę jurysdykcji kościoła, na którą polski ustawodawca ma ograniczony wpływ. Zastosowanie znajduje tu zasada wyrażona $\mathrm{w}$ art. 2 ustawy o stosunku państwa do Kościoła Katolickiego w RP, zgodnie z którym Kościół rządzi się w swych sprawach własnym prawem, swobodnie wykonuje władzę duchowną i jurysdykcyjna, oraz zarządza swoimi sprawami ${ }^{18}$.

Tarcza 4.0 wprowadziła do art. $15 \mathrm{~g}$ ust. 1 kolejną kategorię podmiotów uprawnionych do wnioskowania o dofinansowanie do wyna-

18 B. Rakoczy: Ustawa o stosunku państwa do kościoła katolickiego w Polsce. Komentarz. Oficyna 2008. 
grodzeń pracowników - są to państwowe lub prowadzone wspólnie z ministrem właściwym do spraw kultury i ochrony dziedzictwa narodowego instytucje kultury $\mathrm{w}$ rozumieniu ustawy z dnia 25 października 1991 r. o organizowaniu i prowadzeniu działalności kulturalnej, w których wystąpił spadek przychodów w następstwie wystąpienia COVID-19. Wprowadzono również ust. 1a, który prawo do wnioskowania o dofinansowanie rozciągnął również na samorządowe instytucje kultury, w których wystąpił spadek przychodów związanych z wystąpieniem COVID-19. Są to niewątpliwie podmioty o dość jednorodnym charakterze. Zastanawia więc, dlaczego zamiast ująć obydwie kategorie podmiotów w jednym przepisie - na przykład obydwa $\mathrm{w}$ art. $15 \mathrm{~g}$ ust. 1 lub obydwa $\mathrm{w}$ art. $15 \mathrm{~g}$ ust. $1 \mathrm{a}-$ zostały $\mathrm{w}$ taki sposób, sztucznie, rozdzielone. Prawdopodobnym wytłumaczeniem jest nieco odmienne ukształtowanie źródeł dofinansowania. W przypadku państwowych instytucji kultury jest ono w całości finansowane przez Fundusz Gwarantowanych Świadczeń Pracowniczych - podobnie jak $\mathrm{w}$ przypadku pozostałych podmiotów wskazanych $\mathrm{w}$ art. $15 \mathrm{~g}$ ust. 1. W przypadku samorządowych instytucji kultury dofinansowanie jest pokrywane częściowo przez FGŚP, częściowo zaś przez organizatora działalności. Zastanawia również wprowadzona w stosunku do tych kategorii podmiotów dodatkowa przesłanka spadku przychodów związana z COVID-19, a zwłaszcza jej relacja do ogólnej przesłanki spadku obrotów gospodarczych, o której mowa w ust. 1 i która uszczegółowiona została w ust. 15g ust. 9. W przypadku samorządowych instytucji kultury - ponieważ zostało to uregulowane odrębnie w ust. 1a - kryterium spadku przychodów niejako zastępuje kryterium spadku obrotów gospodarczych. Jednak w przypadku instytucji kultury państwowych lub prowadzonych wspólnie z ministrem właściwym do spraw kultury i ochrony dziedzictwa narodowego, które zostały wymienione $w$ ust. 1, sprawa nie jest już oczywista. Dodatkowo należy odnotować, że - odmiennie niż w stosunku do innej kategorii podmiotów - nie wprowadzono żadnej granicy minimalnego spadku przychodów uprawniających do występowania o dofinansowanie do wynagrodzeń.

Tarczą 3.0 ustawodawca upoważnił do występowania o wypłatę świadczeń na dofinansowanie do wynagrodzeń państwowe osoby prawne, o których mowa w ustawie o finansach publicznych. Defi- 
nicja legalna państwowej osoby prawnej zawarta jest $\mathrm{w}$ art. 3 ustawy z 16 grudnia 2016 r. o zasadach zarządzania mieniem państwowym ${ }^{19}$. $\mathrm{Na}$ mocy tego przepisu prawo do wnioskowania o dofinansowanie do wypłaty świadczeń uzyskały agencje wykonawcze, państwowe fundusze celowe posiadające osobowość prawną (np. NFZ), instytucje gospodarki budżetowej, uczelnie publiczne utworzone przez państwo, reprezentowane przez właściwy organ władzy lub administracji rządowej ${ }^{20}$. To rozwiązanie, jak się jednak później okazało, miało charakter efemeryczny, bo - już po kilku tygodniach obowiązywania w Tarczy 4.0 ustawodawca wyłączył tę kategorię podmiotów z zakresu art. $15 \mathrm{~g}$ ust. 1.

\section{Podmioty pozbawione prawa do występowania o dofinansowanie do wynagrodzeń pracowników}

Interesujące jest również spojrzenie na zakres podmiotowy art. 15g ust. 1 od strony negatywnej, czyli analizując krąg podmiotów, które możliwości ubiegania się o dofinansowanie do wynagrodzeń pracowników z Funduszu Gwarantowanych Świadczeń Pracowniczych zostały pozbawione. Nie pretenduję $\mathrm{w}$ tym przypadku do stworzenia wyczerpującego katalogu tych podmiotów. Jednak praktyka pokazuje, że niektóre kategorie podmiotów zostały pozbawione możliwości korzystania z tej formy wsparcia pomimo znajdowania się z powodu epidemii COVID-19 i związanych z nią ograniczeń w prowadzeniu działalności w porównywalnie trudnej sytuacji co podmioty, które z tych świadczeń mogą skorzystać, co budziło szczególnie dużo wątpliwości.

Nie są objęte zakresem podmiotowym art. $15 \mathrm{~g}$ ust. 1 ustawy o COVID-19 oddziały przedsiębiorstw zagranicznych ${ }^{21}$, prowadzące działalność gospodarczą na podstawie ustawy z dnia 6 marca $2018 \mathrm{r}$. o zasadach uczestnictwa przedsiębiorców zagranicznych i innych osób zagranicznych $\mathrm{w}$ obrocie gospodarczym na terytorium $\mathrm{RP}^{22}$. Zgodnie $\mathrm{z}$ art. 3 pkt. 4 powołanej ustawy oddział oznacza wyodrębnioną i samodzielną organizacyjnie część działalności gospodarczej, wykonywaną przez przedsiębiorcę poza siedzibą przedsiębiorcy lub głównym

19 Dz.U. 2020, poz. 735 ze zm.

${ }^{20}$ Por. K. KsIĘŻYK, w: Tarcza..., s. 147.

21 Ł. PisarczyK, A. Boguska: Sfera zatrudnienia..., s. 3.

${ }^{22}$ Tj. Dz.U. 2020, poz. 1252. 
miejscem wykonywania działalności. Oddział przedsiębiorcy zagranicznego nie może być uznany za przedsiębiorcę $\mathrm{w}$ rozumieniu art. 4 ust. 1 ustawy prawo przedsiębiorców z dwóch powodów. Po pierwsze - nie ma osobowości prawnej ani, nie będąc osobą prawną zdolności prawnej nadanej ustawą ${ }^{23}$. Nie spełnia zatem kryterium podmiotowego, definiującego status przedsiębiorcy w rozumieniu art. 4 ust. 1 ustawy prawo przedsiębiorców. Po drugie - nie wykonuje działalności gospodarczej we własnym imieniu, ale $\mathrm{w}$ imieniu przedsiębiorcy zagranicznego. Przedsiębiorcą $\mathrm{w}$ rozumieniu art. 4 ust. 1 ustawy prawo przedsiębiorców jest natomiast podmiot prowadzący działalność gospodarczą we własnym imieniu.

Prawa do występowania o dofinansowanie zostały również pozbawione podmioty, które art. 6 ust. 1 ustawy prawo przedsiębiorców expressis verbis pozbawił statusu przedsiębiorców, w szczególności dotyczy to działalności wytwórczej $\mathrm{w}$ rolnictwie $\mathrm{w}$ zakresie upraw rolnych oraz chowu i hodowli zwierząt, ogrodnictwa, warzywnictwa, leśnictwa i rybactwa śródlądowego. Art. 6 ustawy prawo przedsiębiorców stanowi, że do tego rodzaju działalności przepisów ustawy się nie stosuje, co za tym idzie, nie są one przedsiębiorcami w rozumieniu art. 4 ust. 1 i 2 prawa przedsiębiorców.

Duże wątpliwości dotyczą podmiotów, co do których ustawy regulujące ich funkcjonowanie zastrzegają że prowadzona przez nie działalność nie jest działalnością gospodarczą. Dotyczy to w szczególności szkół wyższych, w odniesieniu do których art. 425 ustawy prawo o szkolnictwie wyższym i nauce ${ }^{24}$ stanowi, że wykonywanie przez uczelnię zadań, o których mowa $\mathrm{w}$ art. 11 (dot. podstawowej działalności uczelni) oraz prowadzenie działalności sportowej, rehabilitacyjnej lub diagnostycznej nie stanowi działalności gospodarczej w rozumieniu przepisów ustawy prawo przedsiębiorców. Skoro zaś działalność podstawowa uczelni nie jest działalnością gospodarcza, uczelni nie można uznać za przedsiębiorcę ${ }^{25}$. Konstytutywnym elementem definicji przedsiębiorcy jest bowiem prowadzenie działalności gospodarczej. Należy jednak odnotować, że zgodnie z art. 12 ustawy

${ }^{23}$ K. KsIĘŻYK, w: Tarcza..., s. 144.

${ }^{24}$ Tj. Dz.U. 2020, poz. 85.

${ }^{25}$ Por. K. Ksıє̨żYK, w: Tarcza..., s. 141, tak również M. Latos-MiŁкowsкa: Status prawny uczelni w świetle ustawy o ochronie roszczeń pracowniczych w razie niewyptacalności pracodawcy. „Praca i Zabezpieczenie Społeczne” 2019, nr 8, s. 30. 
prawo o szkolnictwie wyższym i nauce uczelnia wyższa może prowadzić działalność gospodarczą wyodrębnioną organizacyjnie i finansowo od działalności podstawowej i z tego tytułu nabywa status przedsiębiorcy w rozumieniu art. 4 ust. 1 ustawy prawo przedsiębiorców ${ }^{26}$.

Podobnie rzecz się ma z niepublicznymi szkołami i przedszkolami. Zgodnie $\mathrm{z}$ art. 170 ustawy prawo oświatowe ${ }^{27}$ prowadzenie szkół i przedszkoli (również niepublicznych) nie jest działalnością gospodarczą. Podobnie jak w przypadku szkół wyższych, pozbawia je to statusu przedsiębiorcy ${ }^{28}$. W tym jednak przypadku dodatkowe trudności interpretacyjne wynikają z okoliczności, że prowadzić szkoły lub przedszkola mogą osoby prawne lub osoby fizyczne, które - prócz szkoły lub przedszkola - prowadzić również mogą inną działalność (np. żłobek), z tytułu czego uzyskują status przedsiębiorcy w rozumieniu art. 4 ust. 1 lub 2 ustawy prawo przedsiębiorców. W takim przypadku powstaje pytanie, czy podmiot taki ma prawo do ubiegania się o dofinansowanie do wynagrodzeń wszystkich pracowników, czy tylko tych, którzy nie są zatrudnieni w placówce oświatowej.

\section{Definicja pracownika}

Od strony pracowniczej zakres podmiotowy dofinansowania do wynagrodzenia pracowników ze środków FGŚP wyznacza art. 15g ust. 4. Zgodnie z tym przepisem pracownikiem, o którym mowa $\mathrm{w}$ ust. 1, jest osoba fizyczna, zgodnie z przepisami prawa polskiego pozostająca $\mathrm{z}$ pracodawcą $\mathrm{w}$ stosunku pracy. Przepis ust. 1 stosuje się odpowiednio do osób zatrudnionych na podstawie umowy o pracę nakładczą, umowy zlecenia albo innej umowy o świadczenie usług, do której zgodnie z ustawą z 23 kwietnia 1964 r. kodeks cywilny stosuje się przepisy dotyczące zlecenia, albo która wykonuje pracę zarobkową na podstawie innej niż stosunek pracy na rzecz pracodawcy będącego rolniczą spółdzielnią produkcyjną lub inną spółdzielnią zajmującą się produkcją rolna, jeżeli z tego tytułu podlega obowiązkowi ubezpieczeń: emerytalnemu i rentowemu, z wyjątkiem pomocy domowej zatrudnionej przez osobę fizyczną. Kształtując zakres podmiotowy

${ }^{26}$ M. Latos-Miєкowska: Status prawny..., s. 30.

27 Tj. Dz.U. 2020, poz. 910.

${ }_{28}$ M. Pilich, w: Komentarz do ustawy - Prawo oświatowe. W: Prawo oświatowe oraz przepisy wprowadzające. Red. M. PILICH. WPK 2018, sip.lex.pl. 
osób uprawnionych do uzyskania dofinansowania do wynagrodzeń ustawodawca w wyraźny sposób nawiązuje do definicji pracownika $\mathrm{z}$ art. 10 ustawy o ochronie roszczeń pracowniczych $\mathrm{w}$ razie niewypłacalności pracodawcy.

Konstrukcja art. $15 \mathrm{~g}$ ust. 4 ustawy o COVID-19 jest niejednorodna, składa się bowiem z definicji pojęcia pracownika, którym jest w myśl tego przepisu osoba fizyczna, która zgodnie z przepisami polskiego prawa pracy pozostaje $\mathrm{z}$ pracodawcą $\mathrm{w}$ stosunku pracy oraz naka$\mathrm{zu}$ odpowiedniego stosowania ust. 1 do enumeratywnie wyliczonych osób świadczących pracę na innej podstawie niż stosunek pracy ${ }^{29}$. Zastanawia jednak, w jakim celu ustawodawca posłużył się tego rodzaju odesłaniem wewnątrz jednostki redakcyjnej. Wydaje się, że zabieg ten jest całkowicie zbędny - ten sam efekt ustawodawca osiągnąłby po prostu wymieniając $\mathrm{w}$ przepisie poszczególne podstawy świadczenia pracy, tak jak to zrobił na przykład w art. 10 ustawy o ochronie roszczeń pracowniczych $\mathrm{w}$ razie niewypłacalności pracodawcy ${ }^{30}$.

Zakresem podmiotowym art. 15g ust. 4 ustawy o COVID-19 objęci są pracownicy bez względu na podstawę nawiązania stosunku pracy. Warto przy tym zauważyć, że ustawodawca również $\mathrm{w}$ tym przypadku nie odesłał do art. 2 kodeksu pracy, ale utworzył swego rodzaju własną definicję, stanowiąc, że jest to osoba fizyczna pozostająca $\mathrm{z}$ pracodawcą $\mathrm{w}$ stosunku pracy $\mathrm{w}$ rozumieniu polskiego prawa pracy. Znowu można się zastanawiać, po co ten dziwny zabieg legislacyjny, który nie wprowadza $\mathrm{w}$ zasadzie żadnej zmiany merytorycznej $\mathrm{w}$ zakresie tego pojęcia ${ }^{31}$. W praktyce niewątpliwie - choćby ze względu na zakres podmiotowy art. 15g ust. 1 - przepis ten będzie dotyczył przede wszystkim pracowników zatrudnionych na podstawie umowy o pracę. Warunkiem jest jednak, aby był to pracownik w rozumieniu prawa polskiego. Jeżeli zatem strony umowy o pracę jako prawo mające zastosowanie do łączącej je umowy o pracę wybiora prawo innego państwa, pracownik nie będzie miał prawa do dofinansowania do wynagrodzenia.

Dofinansowanie, o którym mowa w art. $15 \mathrm{~g}$, przysługuje pracownikom objętym przestojem ekonomicznym lub obniżonym wymiarem

${ }^{29}$ Por. K. KsIĘŻYK, w: Tarcza..., s. 154.

${ }^{30}$ Tj. Dz.U. 2020, poz. 7.

31 Por. K. KsıЕ̨żYK, w: Tarcza..., s. 154. 
czasu pracy, jednak wymiar czasu pracy wskutek obniżenia nie może być niższy niż połowa pełnego etatu. Zatem w przypadku zastosowania $\mathrm{w}$ zakładzie pracy obniżonego wymiaru czasu pracy $\mathrm{z}$ dofinansowania nie będą mogli skorzystać pracownicy zatrudnieni w wymiarze niższym niż połowa pełnego wymiaru czasu pracy. Powyższa przesłanka nie znajduje zastosowania do pracowników uzyskujących dofinansowanie na podstawie art. 15gg ustawy o COVID-19.

Przepisy ust. 1 stosuje się odpowiednio również do osób zatrudnionych na podstawie umowy o pracę nakładcza, umowy zlecenia lub w przypadku osób zatrudnionych na innej podstawie niż stosunek pracy $\mathrm{w}$ rolniczych spółdzielniach produkcyjnych lub spółdzielniach kółek rolniczych. Ochroną objęto zatem również osoby, świadczące pracę $\mathrm{w}$ warunkach zbliżonych do stosunku pracy, pozostające $\mathrm{w}$ ekonomicznej zależności od podmiotu zatrudniającego ${ }^{32}$. Można powiedzieć, że jest to kolejny przejaw zrównywania sytuacji prawnej pracowników i osób świadczących pracę na innej podstawie niż stosunek pracy. W tym jednak przypadku wprowadzono dodatkowe kryterium - umowa musi stanowić tytuł obowiązkowego ubezpieczenia emerytalnego i rentowego. Będzie to miało znaczenie przede wszystkim w przypadku, gdy dana osoba zatrudniona jest na podstawie więcej niż jednej umowy o pracę nakładczą lub umowy zlecenia. W takim bowiem przypadku tytułem ubezpieczenia emerytalno-rentowego jest, co do zasady, tylko pierwsza umowa. Jeżeli z tytułu tej umowy podstawa wymiaru składki jest niższa niż minimalne wynagrodzenie za pracę, wówczas "oskładkowane" są również kolejne umowy (aż zostanie osiągnięta minimalna podstawa wymiaru składek równa minimalnemu wynagrodzeniu za pracę) $)^{33}$. Nie są tytułami obowiązkowego ubezpieczenia emerytalno-rentowego umowy zlecenia lub umowy o prace nakładcza, jeżeli osoba zatrudniona jest też zatrudniona na podstawie stosunku pracy $u$ innego pracodawcy. Dofinansowania nie będzie można również uzyskać do wynagrodzenia z tytułu umów zlecenia zawartych $\mathrm{w}$ warunkach określonych $\mathrm{w}$ art. 8 ust 2a ustawy o systemie ubezpieczeń społecznych. $\mathrm{W}$ takim bowiem przypadku $\mathrm{w}$ orzecznic-

${ }^{32}$ K. KsıĘŻYK, w: Tarcza..., s. 156.

${ }_{33}$ Szeroko na ten temat R. BABIŃsKa-GóRecKa: Ewolucja treści ryzyka socjalnego osób "zatrudnianych" na podstawie umów cywilnoprawnych. W: Umowy cywilnoprawne w ubezpieczeniach społecznych. Red. M. SzabŁowska-Juckiewicz, M. WaŁachowsKa, J. Wantoch-Reкоwsкi. Warszawa 2015. 
twie wykształciła się wykładnia, że tytułem ubezpieczenia jest stosunek pracy, a towarzysząca mu umowa zlecenia nie stanowi odrębnego tytułu ubezpieczenia społecznego ${ }^{34}$. Nie będą również uprawnieni do dofinansowania studenci do lat 26 zatrudnieni na podstawie umowy zlecenia, którzy są ustawowo zwolnieni z obowiązku odprowadzania składek na ubezpieczenie emerytalne i rentowe.

Ratio legis wprowadzenia dodatkowego kryterium jest zapewne chęć objęcia dofinansowaniem tylko tych umów cywilnoprawnych, które są dla osoby świadczącej pracę głównym źródłem zarobkowania ${ }^{35}$. Należy pamiętać, że podstawowym w intencji ustawodawcy celem dofinansowania do wynagrodzeń jest ochrona miejsc pracy. Można zatem zakładać, że chodzi o umowy kreujące względnie trwałą więź między stronami - tylko w takim przypadku można, jak się wydaje, mówić o miejscu pracy ${ }^{36}$.

Zakres podmiotowy osób uprawnionych do dofinansowania wynikający z art. $15 \mathrm{~g}$ ust. 4 nie budzi zasadniczych wątpliwości interpretacyjnych. Niemniej jednak - ze względu na specyficzna, trójpodmiotową formę zatrudnienia - pewne wątpliwości powstają $\mathrm{w}$ odniesieniu do pracowników tymczasowych. Nie ulega wątpliwości, że działalność agencji pracy tymczasowej jest działalnością gospodarczą - przesądza o tym sama treść ustawy o promocji zatrudnienia i instytucjach rynku pracy $^{37}$. Co za tym idzie, agencje pracy tymczasowej są przedsiębiorcami w rozumieniu art. 4 ust. 1 lub 2 ustawy prawo przedsiębiorców i wchodzą w zakres art. 15g ust. 1 ustawy o COVID-19. Nie ulega również wątpliwości, że agencje pracy tymczasowej mogą uzyskiwać dofinansowanie do wynagrodzeń pracowników, których zatrudniają na zasadach kodeksowych i którzy świadczą pracę na ich rzecz. Wątpliwości powstają jednak w odniesieniu do pracowników tymczasowych, dla których agencja pracy tymczasowej jest również pracodawcą $\mathrm{w}$ rozumieniu art. 3 k.p., jednakże zatrudnia ich zgodnie $\mathrm{z}$ art. 2 ustawy o pracy tymczasowej wyłącznie w celu skierowania do pracy do innego podmiotu, zwanego pracodawcą użytkownikiem, który korzysta ze

${ }^{34}$ Por. wyrok SN z dnia 27 kwietnia 2017 r. I UK 182/16.

35 R. BabińsKa-Górecka: Ewolucja..., s. 215.

36 Szerzej na ten temat R. BabińsKa-Górecka: Ewolucja..., por. także M. Latos-MiŁKOWSKa: Ochrona osób zatrudnionych na podstawie umów cywilnoprawnych w razie niewypłacalności pracodawcy. „Praca i Zabezpieczenie Społeczne” 2019, nr 1, s. 41.

37 Tj. Dz.U. 2020, poz. 1409. 
świadczenia pracownika tymczasowego i organizuje jego pracę. Przeciwko przyznaniu dofinansowania do wynagrodzeń pracowników tymczasowych przemawiają następujące argumenty. Po pierwsze, środki na wynagrodzenie pracowników tymczasowych pochodzą de facto od pracodawcy użytkownika, choć de iure podmiotem zobowiązanym do jego wypłaty jest agencja pracy tymczasowej. Jeżeli agencja pracy tymczasowej otrzymałaby środki na wypłatę wynagrodzeń od pracodawcy użytkowania i dodatkowo uzyskałaby jeszcze do nich dofinansowanie, wówczas można mówić o bezpodstawnym wzbogaceniu tej agencji. Agencja pracy tymczasowej nie może również zawrzeć porozumienia o objęciu pracowników tymczasowych przestojem ekonomicznym lub obniżonym wymiarem czasu pracy, są to bowiem kwestie, które reguluje umowa zawierana między agencją pracy tymczasowej a pracodawcą użytkownikiem. Dodatkowo, pracodawca użytkownik w każdej chwili ma prawo do rezygnacji z pracownika tymczasowego. Jeżeli zaś przyjać, że głównym celem regulacji art. $15 \mathrm{~g}$ jest ochrona miejsc pracy, to $\mathrm{w}$ tej specyficznej konstrukcji cel ten nie może być osiągnięty agencja pracy tymczasowej, racjonalnie rzecz ujmując, nie może zagwarantować utrzymania zatrudnienia pracownika tymczasowego przez okres ochronny, ponieważ nie zależy to w zasadzie od jej decyzji. Tym samym, z punktu widzenia wykładni celowościowej i funkcjonalnej, należałoby stwierdzić, że agencja pracy tymczasowej nie może uzyskać dofinansowania do wynagrodzeń pracowników tymczasowych. Nie może się też o takie dofinansowanie ubiegać pracodawca użytkownik, ponieważ (według przeważających poglądów) nie łączy go z pracownikiem tymczasowym stosunek pracy, ani inna więź obligacyjna. Tym samym pracownicy tymczasowi zostali pozbawieni ochrony wynikającej z art. 15g ust. 1, żaden bowiem z podmiotów, z którym pozostają w specyficznej trójpodmiotowej relacji, nie jest uprawniony do wystąpienia o dofinansowanie do ich wynagrodzeń.

\section{Próba odnalezienia aksjologicznych podstaw i oceny regulacji}

Ocena aksjologicznych podstaw analizowanej regulacji jest bardzo trudna. Wydaje się jednak, że z dużą ostrożnością można sformułować kilka wstępnych wniosków. Przede wszystkim trudno jednoznacznie ustalić, jakie kryterium czy też kryteria zadecydowały o kształcie tej 
regulacji. $\mathrm{W}$ art. $15 \mathrm{~g}$ ust. 1 znalazły się bardzo różnorodne podmioty, o zróżnicowanym statusie, celu funkcjonowania i zasadach finansowania działalności.

Jeżeli kryterium tym miało być objęcie danego podmiotu ograniczeniami w prowadzeniu działalności na skutek epidemii i spowodowane tym negatywne konsekwencje finansowe, to nie da się racjonalnie wytłumaczyć pozbawienia prawa do dofinansowania niepublicznych szkół i przedszkoli, które na skutek lockdownu przez kilka miesięcy były zamknięte i w ogóle nie mogły funkcjonować. Trudno jest również z tego punktu widzenia wytłumaczyć pozbawienie wsparcia oddziałów przedsiębiorstw zagranicznych, które były poddane takim samym ograniczeniom działalności, co polskie przedsiębiorstwa. $\mathrm{Z}$ drugiej strony, ustawodawca upoważnił do korzystania $\mathrm{z}$ tej formy wsparcia podmioty, które uzyskują finansowanie z innych źródeł niż tylko prowadzenie działalności gospodarczej, przez co ich sytuacja na skutek lockdownu nie musiała ulec tak znacznemu pogorszeniu, jak miało to miejsce $\mathrm{w}$ przypadku przedsiębiorstw dotkniętych ograniczeniami działalności. Dotyczy to na przykład podmiotów z kategorii organizacji pozarządowych, dla których działalność gospodarcza ma charakter subsydiarny, i które czerpią swoje dochody głównie z innych źródeł: np. składek członkowskich, dotacji czy - w przypadku organizacji pożytku publicznego - również odpisów podatkowych. Przejściowo w katalogu podmiotów uprawnionych do świadczeń znalazły się nawet państwowe osoby prawne, których źródłem finansowania są środki budżetowe i inne daniny publiczne.

Jeżeli przyjąć, że podstawowym celem regulacji była ochrona miejsc pracy, to również przy takim kryterium pojawia się szereg niekonsekwencji. Wsparcia pozbawione zostały oddziały przedsiębiorstw zagranicznych, będące niekiedy bardzo dużymi pracodawcami. Wsparcia został pozbawiony również sektor niepublicznego szkolnictwa wyższego oraz niepubliczne szkoły i przedszkola, mimo istotnego znaczenia społecznego i generowania dużej liczby miejsc pracy. Wszystkie te podmioty nie tylko znajdowały się $\mathrm{w}$ okresie lockdownu $\mathrm{w}$ sytuacji niemożności lub ograniczenia możliwości prowadzenia działalności, ale również ponoszą jednakowe $\mathrm{z}$ pozostałymi pracodawcami koszty związane z zatrudnianiem pracowników, w tym składki na ubezpieczenie społeczne, składki zdrowotne, Fundusz Gwarantowanych 
Świadczeń Pracowniczych i Fundusz Pracy. W mojej ocenie w stosunku do tych kategorii podmiotów doszło do naruszenia konstytucyjnej zasady równości wobec prawa.

Nie wydaje się, by można odkodować jednoznaczne aksjologiczne podstawy tej regulacji. Ciągłe zmiany art. $15 \mathrm{~g}$ ust. 1 wskazuja że sam ustawodawca nie mógł do końca zdecydować, jakim podmiotom udzielić pomocy. Częściowo można to tłumaczyć szczególnymi okolicznościami i tempem, w jakim regulacja powstawała, oraz związanym z tym brakiem czasu na pogłębioną refleksję. Ustawodawca starał się na bieżąco dostosowywać regulacje do zmieniającej się dynamicznie sytuacji. Nie wszystkie jednak mankamenty da się wyjaśnić pośpiechem i szczególnymi uwarunkowaniami - pewne wady przyjmowanych rozwiązań, zwłaszcza wspomniane wyżej naruszenie zasady równości wobec prawa, były sygnalizowane już na początku obowiązywania Tarczy antykryzysowej, i nie zostały w kolejnych odsłonach skorygowane.

Wrażenie chaosu i braku przejrzystości pogłębia również niski poziom techniki legislacyjnej. Art. 15g ust. 1 jest nieczytelny, miejscami niespójny, nasuwa liczne wątpliwości interpretacyjne, zawiera wewnętrzne powtórzenia (np. dotyczące kościelnych osób prawnych i ich jednostek organizacyjnych). Być może lepsze efekty ustawodawca osiągnąłby, gdyby - w miejsce sprawiającego niekiedy wrażenie przypadkowości wyliczania podmiotów uprawnionych do wsparcia - posłużył się $\mathrm{w}$ art. $15 \mathrm{~g}$ ust. 1 bardziej syntetyczna, przemyślaną formułą. Na to jednak $\mathrm{w}$ dynamicznie zmieniającej się sytuacji zapewne zabrakło czasu.

Bardziej czytelny od strony aksjologicznych podstaw regulacji jest art. $15 \mathrm{~g}$ ust. 4 ustawy o COVID-19. Ustawodawca, jako podmioty uprawnione do otrzymania dofinansowania, wskazał pracowników i osoby świadczące pracę zarobkową na rzecz podmiotu zatrudniającego $\mathrm{w}$ warunkach zbliżonych do stosunku pracy, i to należy uznać za decyzję słuszną. Jest to przy tym kolejny przykład zrównywania sytuacji prawnej pracowników i osób zatrudnionych na innych podstawach niż stosunek pracy. Zwraca jednak uwagę niepotrzebnie udziwniona technika legislacyjna - wprowadzenie zbędnej, niczego nie wnoszącej, swoistej definicji pracownika, oraz niepotrzebne odesłanie w zdaniu drugim do enumeratywnie wyliczonych podmiotów świadczących pracę zarobkową na innej podstawie niż stosunek pracy. 
Zakres podmiotowy dofinansowania do wynagrodzeń pracowników...

\section{Bibliografia}

BABIŃsKA-GóReckA R.: Ewolucja treści ryzyka socjalnego osób „zatrudnianych" na podstawie umów cywilnoprawnych. W: Umowy cywilnoprawne w ubezpieczeniach społecznych. Red. M. SzabŁowska-Juckiewicz, M. WaŁachowska, J. Wantoch-Rekowski. Warszawa 2015.

Bielecki R. i in.: Komentarz do ustawy - Prawo przedsiębiorców. W: Konstytucja biznesu. Komentarz. Red. M. Wierzbowski, sip.lex.pl, WKP 2019.

KsıĘżYK K., w: Tarcza antykryzysowa 1.0 - 3.0. Szczególne rozwiąania w prawie pracy, prawie urzędniczym i prawie ubezpieczeń społecznych. Komentarz. Red. K.W. BARAN. Warszawa 2020.

Latos-MiŁkowska M.: Status prawny uczelni w świetle ustawy o ochronie roszczeń pracowniczych w razie niewypłacalności pracodawcy. „Praca i Zabezpieczenie Społeczne" 2019, nr 1.

Latos-MiŁkowska M.: Ochrona osób zatrudnionych na podstawie umów cywilnoprawnych w razie niewypłacalności pracodawcy. „Praca i Zabezpieczenie Społeczne" 2019, nr 1.

Pilich M. (red.). Komentarz do ustawy - Prawo oświatowe. W: Prawo oświatowe oraz przepisy wprowadzajace. WPK, sip.lex.pl 2018.

Pisarczyk Ł., BogusKa A.: Sfera zatrudnienia w dziataniach antykryzysowych. Wybrane zagadnienia. „Monitor Prawa Pracy” 2020, nr 5.

Rakoczy B.: Ustawa o stosunku państwa do kościoła katolickiego w Polsce. Komentarz. Warszawa 2008.

\section{La portée d'application personnelle des subventions salariales versées par le Fonds de garantie des prestations salariales dans le cadre de la lutte contre les effets de l'épidémie de COVID-19}

\section{Résumé}

Le texte est consacré à une analyse du groupe de sujets auquel le législateur a accordé un soutien sous forme de cofinancement salarial à partir du Fonds de garantie des prestations salariales en raison de la dégradation de leur situation financière suite à l'épidémie de COVID-19. Cette disposition soulève des doutes d'interprétation et celles axiologiques. En outre, le catalogue des personnes éligibles a subi de nombreux changements dont l'objectif et la légitimité ont également suscité des controverses. L'auteure propose une analyse critique de ces solutions.

Mots-clés: épidémie, cofinancement salarial, entrepreneur, organisation non gouvernementale, salarié, Fonds de garantie des prestations salariales. 


\section{Zakres podmiotowy dofinansowania do wynagrodzeń pracowników wypłacanego ze środków Funduszu Gwarantowanych Świadczeń Pracowniczych w związku ze zwalczaniem skutków epidemii COVID-19}

\section{Streszczenie}

Niniejszy tekst jest poświęcony analizie kręgu podmiotów, którym ustawodawca udzielił wsparcia w postaci dofinansowania do wynagrodzeń pracowników z Funduszu Gwarantowanych Świadczeń Pracowniczych w związku z pogorszeniem ich sytuacji finansowej w następstwie epidemii COVID-19. Regulacja ta budzi istotne wątpliwości interpretacyjne i aksjologiczne. Dodatkowo katalog uprawnionych ulegał licznym i dynamicznym zmianom, których cel i zasadność również budziły kontrowersje. Autorka stara się dokonać analizy tych rozwiązań i poddać je krytycznej analizie.

Słowa kluczowe: epidemia, dofinansowanie do wynagrodzeń, przedsiębiorca, organizacja pozarządowa, pracownik, Fundusz Gwarantowanych Świadczeń Pracowniczych. 